\title{
On the Branching of the Zygopteridean Leaf, and its Relation to the probable 'Pinna' Nature of Gyropteris sinuosa, Goeppert.
}

\author{
BY
}

\author{
BIRBAL SAHNI, B.A. (Cantab.), M.Sc. (Lond.), \\ Research Student, Emmanuel College, Cambridge.
}

With three Figures in the Text.

\section{The Branching of the Zygopteridean Leaf.}

N rgo9 Dr. Paul Bertrand (1) published an exhaustive comparative
account of the Zygopteridean leaf, exhibiting in great detail the complex forms assumed by the vascular strands. A special feature of the work was the attention paid to the branching of the vascular axis of the leaf, to supply the secondary and tertiary axes ('pinnae' and 'pinnules'). Where possible the further branching of the tertiary axes was also described, and the vascular supply to the aphlebiae was traced.

It was Dr. Bertrand's detailed account of Stauropteris oldhamia which allowed the structure of this till then rather puzzling species to be interpreted in terms of the typical Zygopterid leaf-trace. Assuming that the largest axis known is the primary rachis, it is described as bearing altogether four series of pinnae (secondary raches), in pairs alternating on the right and left sides of the leaf. The vascular supply to these branches is as follows : From the cruciate xylem-mass of the primary rachis (Fig. 2, D) a single large strand, elongated in the antero-posterior plane, becomes detached laterally. This is the piece sortante of Bertrand. It never appears to acquire a cortical sheath of its own, for it at once divides, symmetrically along the right and left plane, into two halves, the demi-pieces sortantes of Bertrand. Each of these is described as entering one of the two so-called 'pinnae' (secondary raches) on that side. ${ }^{1}$

If the branching primary axis of Stauropteris were viewed superficially, without regard to the vascular anatomy, it would be perfectly natural to regard the lateral axes as 'secondary' raches. But in the presence of the single embedded strand (pièce sortante) which comes off from the side of the primary petiolar strand, and which by subsequent division gives rise to the

1. These latter in their turn branch in an almost identical fashion, and the process is repeated in several generations of axes; but we need not follow this in detail.

[Arnals of Botany, Vol. XXXII. No. CXXVII. July, 1918.] 
two strands supplying these axes, the latter cannot, I think, be regarded as morphologically equivalent to secondary raches ('pinnae'). There appears to be no alternative but to regard them as tertiary raches ('pinnules'), and the large strand ('piece sortante') still enclosed in the cortex of the primary axis as the strand of a secondary rachis ('pinna') which has not become free. See Fig. I.

Stress has been laid on this apparently unimportant point, for the reason that it has been responsible for a misunderstanding on one point of some theoretical importance: the mode of branching of the frond in some Zygo-

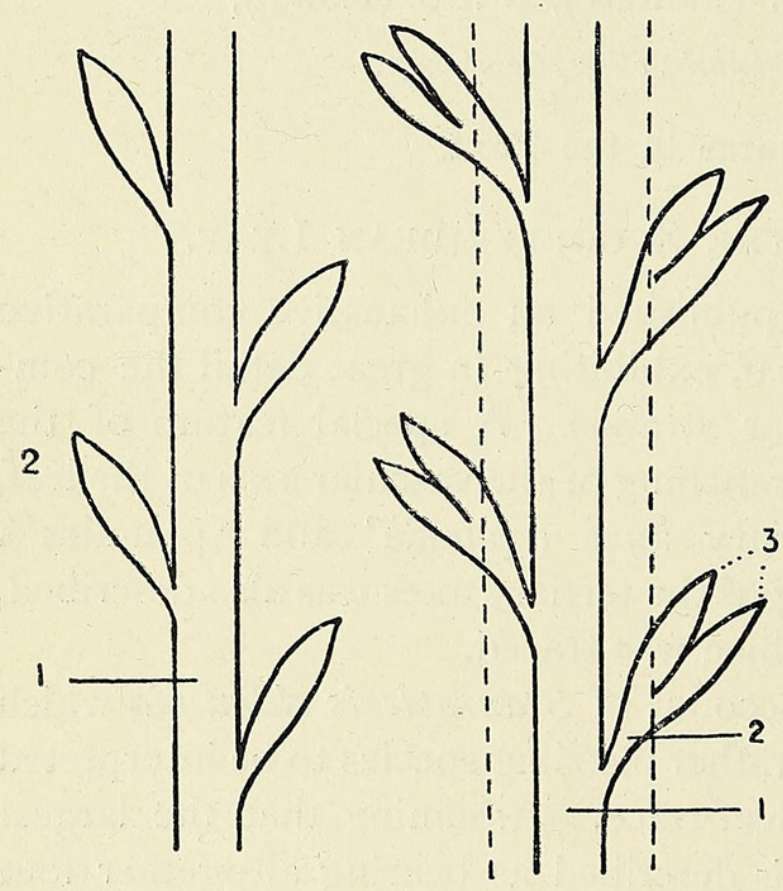

FIG. I. pterideae has been considered to be unique among vascular plants: fronds have been described as bearing four series of pinnae, two on each side of the primary rachis. In some inexplicable way, the morphological significance of the embedded pinna-trace has hitherto escaped the notice of most authors, not only in Stauropteris, but also in Dineuron, Etapteris, Metaclepsydropsis, and Diplolabis. In the two last-named genera Dr. Gordon (5) calls the embedded trace the ' pinna-trace-bar' (p. 716, foot-note) and describes it as subsequently dividing into two 'pinna-traces'. In Etapteris also, where the homologue of the embedded trace is formed by the fusion of two originally separate pieces, neither Bertrand nor Kidston and Gwynne-Vaughan (9) have given it the interpretation which appears to be the only admissible one. Dr. Kidston, however, in Igo8 (7) correctly regards this strand in Dineuron ellipticum, Kidst., and Metaclepsydropsis duplex as a pinna-trace. But the description by Kidston and Gwynne-Vaughan (1910) does not differ in this respect from Bertrand's interpretation.

The condition in Zygopteris primaria, Cotta, unfortunately remains obscure. According to Bertrand (1909, p. I37) it is not possible to say whether the pinna-trace is formed as in Etapteris by the fusion of two originally distinct pieces, or whether it comes off as a single arc and is thus more closely comparable to the condition in Diplolabis, Metaclepsydropsis, and Dineuron. ${ }^{1}$

The misconception, now for the first time cleared up, apparently dates

1 The latter would appear to be more probably the case, for Z. primaria and Diplolabis have 



\section{ERRATUM}

No. CXXVII. Page $37 \mathrm{I}$, line 27

For 'tip of the primary rachis' read 'tip of the secondary rachis'

Annals of Botany CXXIX 
Sahni.-On the Branching of the Zygopteridean Leaf. $37_{\mathrm{I}}$

as far back as 1874 , when Williamson (19) wrote as follows in reference to the branching of the vascular axis of Rachiopteris $(M$.) duplex: 'I know of no recent fern in which the secondary branches [meaning pinnae] of the petiole are thus given off in pairs, which pairs are distichously arranged on the primary axis, and each of which secondary petioles sustains ternary ones arranged distichously. Not only will a similar case come before us on a later page of this Memoir, in Corda's genus Zygopteris, but the structure of the Rachiopteris oldhamia just described suggests the possibility that a somewhat similar arrangement may have existed in its case.' Stenzel, writing in $1889(17)$, divided the genus Zygopteris into two main sections ( $Z$ ygopteris proper and Ankyropteris) according to the biseriate or quadriseriate arrangement of branches which he erroneously regarded as being all secondary raches. Solms-Laubach (15), while justly criticizing Stenzel's classification as being inconsistent on other grounds, passes over the first error unnoticed. Finally, Dr. Bertrand (2), throughout his r9I 2 paper in the 'Progressus', does not depart in this respect from the position he adopted in I909, except that on p. $22 \mathrm{I}$ he suggests that the presence of four rows of appendages in Diplolabis is due to a precocious dichotomy (dichotomie hâtive) of the secondary petioles. After this statement he continues to regard the products of the dichotomy as secondary raches.

There are thus in the Zygopterideae, as in all known vascular plants with pinnate leaves, only two rows of 'pimnae' (secondary raches), one on each side of the leaf, and the supposed radial symmetry of the Stauropterid leaftrace is purely superficial. In some Zygopterideae, however (Diplolabis, \&c.), the whole of the secondary rachis is fused with the primary rachis, though the vascular strands of the two are distinct, while the tertiary raches, formed by a dichotomy of the tip of the primary rachis, are free (Fig. I). Each tertiary rachis then branches monopodially, giving off small strands which supply reduced lateral axes (aphlebiae), which may branch in their turn. The monopodial branching of the tertiary raches is thus clearly seen to be a reduced form of the dichotomous branching of the secondary raches. In other Zygopterideae (Ankyropteris) the secondary raches become free, and branch monopodially to give rise to reduced axes (aphlebiae).

The Zygopterideae (with the sole exception of Stauropteris, according to Dr. Bertrand) are generally considered to be peculiar also on account of the leaf always branching in a rectangular system (édification rectangulaire, Bertrand), the principal plane of each branch-axis being perpendicular to that of its own mother-axis. The leaves of Stauropteris and of all the higher Ferns, Gymnosperms, and Angiosperms are supposed by Bertrand to branch in a parallel system (édification parallèle), so that the branches of all orders face in the same direction.

very similarly shaped leaf-traces, lacking the peculiar horn-like outgrowths of the antennae characteristic of Etapleris. 
So far as Stauropteris is concerned, its supposed édification parallele is clearly the result of Dr. Bertrand's omission to take account of the 'embedded trace'. In Fig. 2, A, the rectangular system of branching is diagrammatically shown. The numbers I, 2, 3, refer to the primary, secondary, and tertiary axes, and may be taken to correspond to the vascular strands of the leaf, pinna, and pinnule in the three types of Zygopterideae shown (B, C, D). The arrows indicate the planes of principal symmetry. In Metaclepsydropsis the tertiary strands, which at some distance from the base almost directly face the antero-posterior plane of the
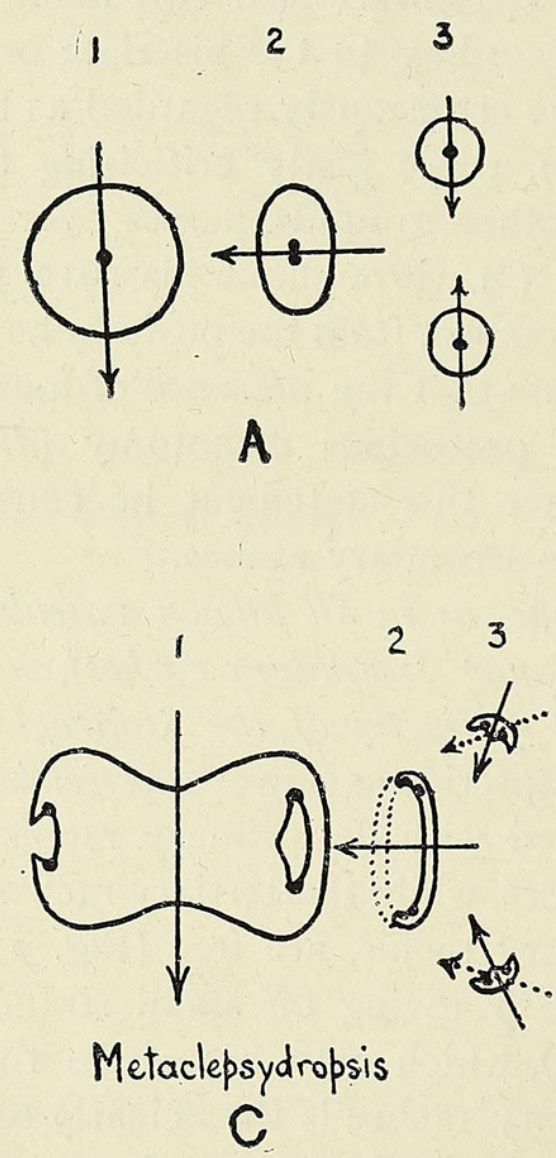

3

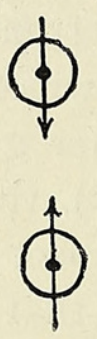

$\oint$

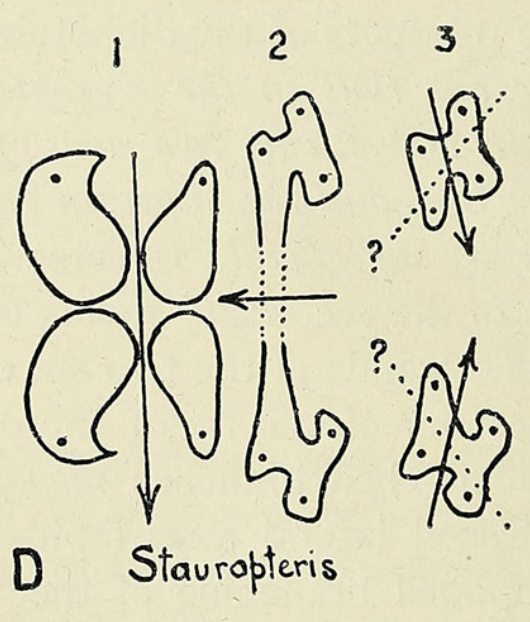

D Stauropteris

3

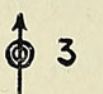

Clepsydropsis

B

Fig. 2.

leaf (as shown by the dotted arrows), are purposely drawn almost facing the right-left plane, in order to diagrammatize. In fact, if they are traced downwards they actually do tend to assume positions nearly facing each other (see Gordon, Figs. 37-40). It is probable that their position higher up the raches was partly responsible for the belief that they were pinnatraces directly facing the primary petiolar trace. In the case of Stauropteris, however, the orientation of the corresponding strands could be verified by other means, viz. the positions of the two main phloem-masses, which, according to Bertrand, invariably lie in the principal plane on each strand. ${ }^{1}$

${ }^{1}$ I am not in a position to vouch for the correctness of the orientation of the tertiary traces as indicated in Fig. 2, D. It is possible that the arrows may have to be drawn as shown by the dotted lines. This would conform more clearly to the condition in $M$. duplex and other species. 
Stauropteris was thus considered to possess pinna-traces facing parallel to the main petiolar trace, and an attempt was made (Bertrand, 1909, p. I77) to explain what was regarded as a surprising anomaly.

Except for Stauropteris our knowledge of the Zygopteridean leaf is still confined to its basal region, and it is too early to generalize as to the probable mode of branching of the distal (laminated) portions of the frond. It is to be borne in mind, however, that a number of frond genera from the same rocks as these raches still remain to be correlated, and that these fronds do not differ materially, in the orientation of their segments, from those of any living Ferns. There is thus a strong presumption that the distal (laminated) portions of the Zygopteridean leaf were in most cases held in a more or less horizontal position, all their segments being expanded in the same plane, as in the modern Ferns. The suggestion put forward by Kidston and Gwynne-Vaughan (1910, p. 474), that the peculiar habit of the Zygopteridean leaf is to be attributed to an erect position, is probably applicable only to the basal wingless portion of the rachis, except in Stauropteris. If, as Dr. Scott (13) has suggested, there were two kinds of leaves, sporangiferous and vegetative, the former appear to have been held strictly erect, at least in the last-named genus.

\section{On the Probable Pinna Nature of Gyropteris sinuosa,} GOEPPERT.

Having arrived at the conclusion that the embedded trace of Diplolabis and similar Zygopterids belongs to a secondary rachis completely enclosed in the primary cortex, the question arose whether any closely allied plant existed in which the secondary rachis became free from the main cortex before dichotomizing. After this I read for the first time a description of Gyropteris simuosa (P. Bertrand, 1909, p. I8I) from the Carboniferous Limestone of Glätzisch-Falkenberg, originally described by Goeppert (4), and was struck by the fact that the shape of its xylem portion was almost identical with that of the pinna-trace of Diplolabis or Metaclepsydropsis, the two latter being almost indistinguishable one from the other. The degree of similarity is indeed so great that it seemed probable that $G$. sinuosa is in reality a 'pinna' enclosed within its own cortex, and belonging to a genus closely allied to, if not identical with, either Metaclepsydropsis or Diplolabis. The transverse section of the vascular strand of Gyropteris measures about $\mathrm{I} \mathrm{cm}$. in length, i. e. more than four times as much as in Metaclepsydropsis, and if the above conjecture has any foundation, the complete plant of Gyropteris must be a giant among the family.

Dr. Bertrand naturally did not fail to notice the resemblance mentioned above, but he dismissed as improbable the idea that $G$. sinuosa is a secondary rachis, and provisionally regarded it as a separate genus. The 


\section{Sahni.-On the Branching of the Zygopteridean Leaf.}

true conception of the embedded trace of Metaclepsydropsis, however, throws a weight of argument in favour of the conjecture, which was not available to Dr. Bertrand.

\section{Distribution AND AfFinities.}

The discovery in the Australian region (see below, p. 375) of a member of the Zygopterideae, a family until recently known only from Europe and West Siberia, is of considerable interest. It is one more piece of evidence in support of a fact which has repeatedly been demonstrated in the past, namely, the essential similarity of the ancient floras (and faunas) of regions of the earth now widely separated by the sea. To take the most recent case, we know that the world-wide distribution of the modern Osmundaceae has been known, within the last few decades, to have been almost paralleled by that of the fossil representatives of the family. The recent work of Dr. Kidston and the late Professor Gwynne-Vaughan has established a close relation between the fossil Osmundaceae and the $Z$ ygopterideae, and it would not be surprising if members of the latter family are discovered in other parts of the world in rocks underlying those containing Osmundaceous remains.

From anatomical evidence a common ancestry has been advocated for the Coenopterideae and the Osmundaceae $(8$, p. $778 ; 14$, p. 472). It is a striking fact, however, that whereas the Coenopterideae are known to extend down to Upper Devonian times, the earliest record of the Osmundaceae is only in the Upper Permian (9, Table, p. 465). The Coenopterideae were indeed just becoming extinct when, as far as present knowledge goes, the Osmundaceae began to make their appearance. A time relation of this kind between two undoubtedly closely allied groups would seem to suggest, although somewhat vaguely, that the older group may have stood towards the younger in the relation of an ancestor. It is, however, too early to speculate on the latter view : we have not yet arrived at the limit of primitiveness which the Osmundaceae probably attained, and in the earlier rocks forms may yet be discovered which it would be difficult to assign to one or the other of these two families.

Indeed, it may be that we already have one such form in Grammatopteris Rigolloti, B. Ren. (12), although it has not yet been recorded from rocks older than the Permo-Carboniferous. As Kidston and GwynneVaughan $(8$, p. 778$)$ have remarked, this species may be a near approach to the primitive Osmundaceous type; at the same time the leaf-trace bears undoubted resemblance to that of Dineuron.

A few words are necessary in connexion with the affinities of some of the Zygopterideae. In classifying the different $Z$ ygopterid petioles Kidston and $\mathrm{G}$ wynne-Vaughan $(9$, p. 470$)$ have expressed the opinion that the most 
important and far-reaching. distinction is based upon the biseriate or quadriseriate arrangement of the (free) branch-axes of the leaf. In the quadriseriate forms the free branches are, as we have seen, tertiary raches formed by the terminal forking of the adnate secondary raches; in the biseriate forms the secondary raches themselves are free, and do not fork. This distinction is associated with important differences in the mode of branching of the vascular strands.

However, if there is any foundation for the suggestion that Gyropteris simuosa is the free secondary rachis of a form like Metaclepsydropsis duplex or Diplolabis, a classification mainly based on the external characters would no longer be tenable. In any case it seems preferable to rely more upon the vascular structures.

The most recent scheme of phylogeny (2) is the combined result of the work of Dr. Gordon and Dr. Bertrand. In attempting to elucidate the closer relations of the genus Stauropteris, the latter author concludes that of all the Zygopterideae the closest resemblance is that with Ankyropteris bibractensis, var. westphaliensis, P. Bertr. (1909, p. I64). The different parts of the two leaf-traces are closely compared, and the ' filament' of Ankyropteris is represented as being fused indistinguishably to the side of the Stauropterid leaf-trace (see Fig. 24, p. 169). In face of the clear resemblances with Diplolabis and similar forms it is very doubtful that the comparison instituted by Dr. Bertrand is admissible. Stauropteris, like Diplolabis, has two planes of symmetry in the leaf-trace; the pinna-trace arises in both genera by the meeting of two processes, and in both genera it at once dichotomizes. In all these respects the leaf-trace of Ankyropteris westphaliensis is different: it has only one plane of symmetry; the pinnatrace arises as a closed ring, and in a manner which even for that genus is peculiar to this species; moreover, the pinna-trace does not fork.

In I9I5 Mrs. E. M. Osborn (11) briefly described an important fossil from New South Wales, which, while possessing the Ankyropteris Grayi type of cauline stele, had leaf-traces similar to those of Clepsydropsis antiqua, Unger. The origin of the leaf-trace resembles that known for A. corrugata and-except for the absence of axillary branches-for $A$. Grayi. A short account of a similar but incomplete fossil, from a different locality in New South Wales, was read before the Cambridge Philosophical Society on February 19, 1917, and the full paper will appear in a future number of the 'Annals'. I have since learnt from Mrs. Osborn that the two plants are specifically identical.

I have no doubt that the stem-structure and leaf-trace origin in Clepsydropsis antiqua and $C$. kirgisica was essentially similar to that in the Australian fossil, and that the two genera Clepsydropsis and Ankyropteris should be united. ${ }^{1}$ In view of this I had at first included the former genus

\footnotetext{
1 A more complete discussion of this question is given in my forthcoming paper.
} 


\section{Sahni.-On the Branching of the Zygopteridean Leaf.}

in the latter. Since then, however, I have had an opportunity of discussing the paper with Dr. D. H. Scott, F.R.S.. I am indeed very thankful to him for his able criticism, and for drawing my attention to the question of priority in nomenclature, which I had not fully considered. The much older genus Clepsydropsis (Unger, I856) should stand, and the more recent genus Ankyropteris (P. Bertrand, 1909) should be merged in Clepsydropsis. The name Ankyropteris was first employed by Stenzel in I889 (17) for one of his sections of Corda's genus Zygopteris (I 845).

The diagnosis of the genus Clepsydropsis as now extended would be as follows :

Stem with or without 'axillary branches', or more or less equally forked. Cauline stele, with a solid outer xylem and a stellate 'mixed

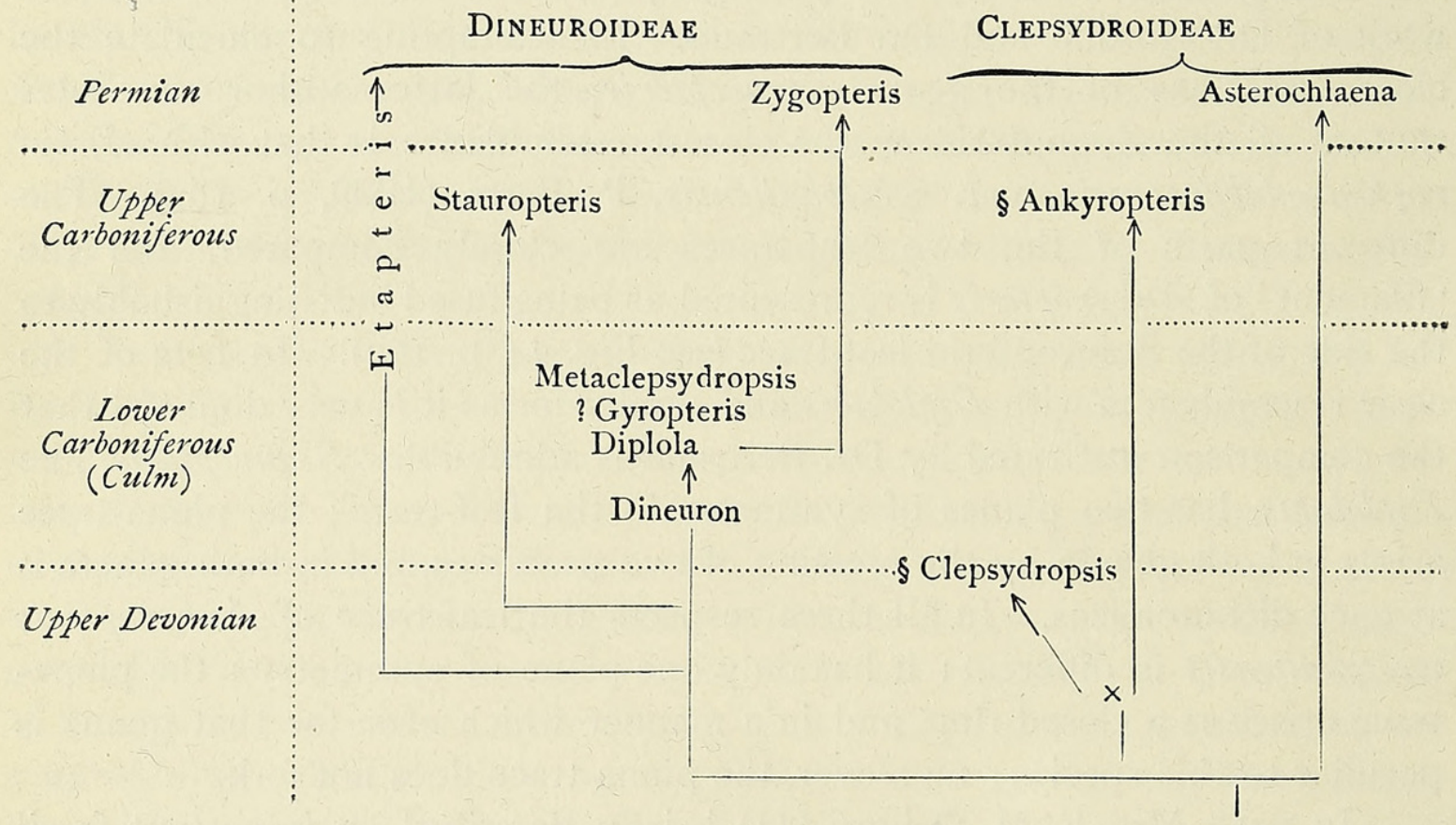

FIG. 3. Table showing inter-relations of the genera of Zygopterideae. Modified from P. Bertrand (I9I2).

pith ' or internal xylem. Leaf-traces in $\frac{2}{5}$ phyllotaxis, nipped off as closed rings, and distally becoming clepsydroid. Pinna-traces arising as closed rings and branching laterally at the base to supply similar traces to aphlebiae. Roots diarch. Known range: Upper Devonian to Upper Carboniferous (inclusive).

The known species of the genus naturally fall into two sections :

I. $\S$ Clepsydropsis proper.-Peripheral loops extended in the rightleft plane (C. antiqua, Unger; C. kirgisica, Stenzel ; and Mrs. Osborn's fossil).

2. \& Ankyropteris.-Peripheral loops extended antero-posteriorly (including all the species hitherto recognized under the genus Ankyropteris, P. Bertrand). 
The two sections possibly diverged from a hypothetical Devonian species of the genus (see Table, Fig. 3) which had circular loops. Kidston and Gwynne-Vaughan (9) have already commented upon the tendency in some Zygopterideae to extend their peripheral loops in the antero-posterior direction. The four Upper Carboniferous species of Clepsydropsis, $C$. (Ankyropteris) Williamsoni, cornugata, Grayi, westphaliensis, belonging to the section Ankyropteris, are named in order according to the degree of this extension.

C. westphaliensis would seem to be the most specialized; its peculiar mode of pinna-trace formation, in which process the 'filament' is reinforced by the 'antenna', is probably the result of the feebleness of the 'filament' to nip off a closed ring on its own account.

I am indebted to Dr. Scott for criticism on another point which I had omitted to discuss for considerations of space. As is well known, the pinnatrace in the genera Metaclepsydropsis, Diplolabis, Stauropteris, and Dineuron comes off as a single piece, while in Etapteris it arises in two distinct pieces which soon unite. It might at first seem doubtful, as Dr. Scott pointed out to me, that there is in Etapteris also a single row of pinna-traces on each side of the leaf-trace. This objection is adequately met by saying, as Dr. Gordon has already done $(6, \mathrm{p} .186)$, that Etapteris has a more highly specialized form of pinna-trace origin than the other four genera, with which (see above, p. 370, foot-note) probably Zygopieris primaria will also have to be reckoned. In this respect Etapteris would thus stand towards the other genera of Zygopterideae as many higher Ferns with a double leaf-trace stand towards others with simple traces.

Incidentally, it is tempting to follow up the above analogy a little farther. The tissue filling up the peripheral loops of the leaf-trace, and also that enclosed by the pinna- and aphlebia-traces, is in origin a portion of, or at least homologous with, the 'mixed pith' or internal xylem of the stem, while the rest of the trace is its external xylem. Professor Lang (10, p. 239) has already compared the outer and inner xylems of the Ophioglossaceae to the similarly named tissues in the Zygopterideae. The Clepsydropsis type of leaf-trace and pinna-trace, which does not cause a gap in the external xylem, may thus stand to the condition seen in Diplolabis, \&c. (where a gap is caused, for the loop 'opens'), in the same relation as corresponding types of leaf-trace origin observed by Professor Lang in Botrychium Lunaria (10, p. 237). The gapless condition would thus by analogy indicate a lower organization than that in which the continuity of the external xylem is disturbed.

In fact, this is another important character upon the basis of which the Zygopterid petioles may be divided into the two groups referred to on p. 374. These two groups may conveniently be called, after their most primitive genera- 


\section{Sahni.-On the Branching of the Zygopteridean Leaf.}

I. The Clepsydroideae (including the genera Clepsydropsis as now extended, and Asterochlaena, Corda), and

2. The Dineuroideae (including Dineuron, Diplolabis, Metaclepsydropsis, ? Gyropteris, Zygopteris, Etapteris, and Stauropteris).

The gap between the two lateral xylem-masses of the Stauropterid leaf-trace must then be compared to the open peripheral loops of the other Dineuroideae.

\section{Conclusions.}

I. There are in all $Z$ ygopterideae, as in all known plants with pinnate leaves, only two rows of pinnae (secondary raches), one on each side of the leaf. The supposed secondary raches of Stauropteris, Metaclepsydropsis, Diplolabis, Dineuron, and Etapteris are really tertiary, and the result of the forking of the true secondary raches. The latter are completely fused to the primary rachis, but their strands are distinct.

2. This conclusion revives the suggestion (dismissed by Dr. Bertrand as improbable) that Gyropteris simuosa, Goeppert, is a secondary rachis of a form like Metaclepsydropsis or Diplolabis, in which this organ acquired a cortical sheath independent of the primary rachis.

3. The mode of branching of the Stauropteris leaf conforms to a rectangular system (édification rectangulaire, P. Bertrand) in which the principal plane of each branch-axis is perpendicular to that of its own mother-axis. The supposed radial symmetry of the leaf-trace in this genus is only superficial.

4. The laminated portions of the Zygopterid leaf were probably held in a more or less horizontal position, with all the segments expanded in the same plane, as in the modern Ferns.

5. Unger's genus Clepsydropsis ( 1856 ) is extended to include the genus Ankyropteris, P. Bertrand (1909), and is divided into two sections named after the two original genera.

The Zygopterideae are divided, on the basis of the vascular structure, into the two sub-families Clepsydroideae and Dineuroideae, after the names of their most primitive genera. In the Clepsydroideae, which are the more primitive group, and include the genera Clepsydropsis and Asterochlaena, the peripheral loops are permanently closed; the pinna-trace arises as a closed ring, and branches monopodially at the base to supply similarly shaped aphlebia-traces. In the Dineuroideae, including the remaining genera of Zygopterideae, the peripheral loops open at each pinna-trace exit; the pinna-trace is an open arc, and dichotomizes into two equivalent pinnuletraces. These may branch monopodially at the base to supply similar aphlebia-traces. The relations of the genera are shown in the table (p. 376), which is a modification of Dr. Bertrand's latest scheme.

It is my pleasant duty to express my heartfelt thanks to Professor 
Seward, who has been a constant source of help and encouragement. This work was carried out during the tenure of a Research Studentship at Emmanuel College, Cambridge, and of a grant from the Dixon Fund of the University of London.

\section{The Botany School, Cambridge,} November 6, $191 \%$

\section{BIBLIOGRAPHY.}

1. Bertrand, Paul (1909): Études sur la fronde des Zygoptéridées. Lilie.

2. - (1912): L'étude anatomique des fougères anciennes, \&c. Progressus rei botanciae, vol. iv, pp. 182-302.

3. (1911): Nouvelles remarques sur la fronde des Zygoptéridées, pp. 18-23, Pl. I, Figs. 7-10, Pl. II, Fig. I8.

4. Goeppert (1852): Die fossile Flora des Uebergangsgebirges. Nova Acta Acad. Caes. Leop.• Carol., vol. xxii, Suppl.

5. Gordon, W. T. (1911): On the Structure and Affinities of Diplolabis roemeri (Solms). Trans. Roy. Soc. Edinb., vol. xlvii, Part 4, No. 24.

6. (1911): On the Structure and Affinities of Metaclepsydropsis duplex (Williamson). Trans. Roy. Soc. Edinb., vol. xlviii, Part I, No. 8.

7. Kidston, R. (1908): On a New Species of Dineuron, \&c. Trans. Roy. Soc. Edinb., vol. xlvi, Part 2, No. I6.

8. and Gwynne-Vaughan, D. T. (1907): On the Fossil Osmundaceae. Part I. Trans. Roy. Suc. Edinb., vol. xlv, Part 3, No. 27.

9. (1910): On the Fossil Osmundaceae. Part 4. Trans. Roy. Soc. Edinb., vol. xlvii, Part 3, No. I7.

10. LANG, W. H. (1913): Annals of Botany, vol. xxvii.

11. Osborn, Mrs. E. M. (1915): Preliminary Observations on an Australian Zygopteris. Brit. Assoc. Annual Report, pp. 727-8.

12. Renault, B. (1896): Bassin houiller et permien d'Autun et d'Épinac, fasc. 4, 'Flore fossile.'

13. ScotT, D. H. (1909): Studies in Fossil Botany, vol. i, pp. 337-8.

14. SeWari), A. C. (1910); Fossil Plants, vol. ii.

15. Solms-Laubach, H., Graf zu (1892): Bot. Zeitung, vol. 1, p. 89.

16. $(1896)$ : Ueber die ... von Unger beschriebenen ... Pflanzenreste des Unterkulm von Saalfeld. Abh. d. kgl. geol. Landesanstalt, Neue Folge, Heft 23.

17. Stenzel, G. (1889): Die Gattung Tubicaulis, Cotta. Mitth. aus dem Kgl. min.-geol. Mus. in Dresden, Heft 8.

18. Unger, F. (1856): In Richter u. Unger, Palaeontologie des Thüringer Waldes. Denkschr. d. k.-k. Akad. Wien, Math.-Naturw. Kl., Bd. xi.

19. Williamson, W. C. (1874): On the Organisation of the Fossil Plants of the Lower CoalMeasures. Phil. Trans. Roy. Soc. London, Part 6: Ferns, p. 693. 


\section{$2 \mathrm{BHL}$ Biodiversity Heritage Library}

Sahni, Birbal. 1918. "On the branching of the zygopteridean leaf, and its relation to the probable 'pinna' nature of Gyropteris sinuosa, Goeppert." Annals of botany 32, 369-379.

https://doi.org/10.1093/oxfordjournals.aob.a089680.

View This Item Online: https://www.biodiversitylibrary.org/item/238284

DOI: https://doi.org/10.1093/oxfordjournals.aob.a089680

Permalink: https://www.biodiversitylibrary.org/partpdf/320223

\section{Holding Institution}

Smithsonian Libraries

\section{Sponsored by}

Biodiversity Heritage Library

\section{Copyright \& Reuse}

Copyright Status: Not in copyright. The BHL knows of no copyright restrictions on this item.

This document was created from content at the Biodiversity Heritage Library, the world's largest open access digital library for biodiversity literature and archives. Visit BHL at https://www.biodiversitylibrary.org. 